\title{
Предпосылки
}

\section{импортозамещения \\ и развития \\ экспорта продукции высоких технологий}

\begin{abstract}
В.К. ФАЛЬЦМАН, доктор экономических наук, Заслуженный деятель науки РФ, Российская академия народного хозяйства и государственной службы при Президенте РФ, Москва. E-mail: m975032@gmail.com
\end{abstract}

В статье анализируются предпосылки, перспективы и ограничения для импортозамещения и развития экспорта в электронной и радиоэлектронной промышленности, ИКТ, связи, IT-продукции, программном обеспечении, производстве персональных компьютеров, телевизоров, медицинской техники, лекарственных средств. Экспортозамещение рассматривается как дополнение импортозамещения.

Ключевые слова: импортозамещение, экспортозамещение,

несырьевой экспорт, высокотехнологичная продукция

Впервые импортозамещение (замена импорта продукцией, произведенной в России) стало актуально после дефолта 1998 г. Из-за повышения цен на импорт вырос спрос на продукцию российского автопрома, на отечественные мясоколбасные изделия, шоколад и др. Россияне больше стали отдыхать внутри страны, вследствие чего $30 \%$ туристических фирм вынуждены были покинуть рынок.

В настоящее время повышенный интерес к проблеме импортозамещения вызван сокращением валютных поступлений от продажи нефти и другого сырья, обвалом валютного курса рубля, удорожанием импортной продукции, а также запретом на ввоз в Россию ряда продуктов (санкции), ставящим под угрозу оборонную, энергетическую и экономическую безопасность страны.

Результаты исследования предпосылок импортозамещения в отраслях ТЭК, оборонном комплексе, машиностроении, химической промышленности, в аграрно-продовольственной сфере, сфере услуг опубликованы в предыдущих статьях автора [1-4]. В настоящей статье дан анализ некоторых предпосылок и ограничений для импортозамещения и развития экспорта в отраслях высоких технологий - электронике и радиоэлектронной промышленности, информационных и коммуникационных технологиях (ИКТ), 
в производстве персональных компьютеров, программного обеспечения, телефонной аппаратуры, телевизоров, медицинской техники и лекарственных средств. Объектом исследования выступают наукоемкие виды экономической деятельности, где особенно сильно проявляются отставание и импортозависимость России. Во всем мире для этих отраслей характерны самые высокие темпы роста производства и обновления продукции.

Как и в предыдущих статьях автора, речь пойдет о долговременных проблемах импортозамещения и развития несырьевого экспорта на перспективу 4-5 и более лет.

\section{Электронная и радиоэлектронная промышленность}

Электроника - одна из самых импортозависимых сфер российской экономики. На долю импорта приходится свыше 80\% ее поступлений в народное хозяйство. Российское производство в основном ограничено сборкой импортных компонентов.

Отказ от импорта в ракетно-космической сфере отбросил бы страну к 1950-1960-м годам, когда российские ракеты «Союз» и «Протон» решали задачи с минимумом импортных компонентов.

Глава компании «Российская электроника» считает, что наша страна может производить все что угодно, вопрос лишь в том, сколько это будет стоить. Российское производство сталкивается с ограниченностью отечественного рынка. Поэтому отечественным компаниям, занимающим всего 0,5\% мирового рынка, трудно конкурировать с транснациональными корпорациями по цене, доступности сервисного обслуживания. Некоторые зарубежные покупатели российской авиационной техники в качестве обязательного условия выдвигают комплектование российских самолетов импортной электроникой, тем самым препятствуя импортозамещению.

Еще одно ограничение связано с сырьевой базой. В электронике широко применяются редкоземельные металлы. Между тем российская цветная металлургия редкоземельных элементов практически прекратила свое существование из-за низкого содержания полезных компонентов в руде. Свыше 90\% производства редкоземельных металлов сейчас сосредоточено в Китае.

Предпосылками для импортозамещения в области российской электроники являются ключевые технологии для системы ГЛОНАСС, радиолокационного оборудования, управления 
воздушным движением. Российские производители конкурентоспособны в областях специальной аппаратуры для воздушнокосмической обороны, управления стратегическими ядерными силами, спецсвязи, средств радиоэлектронной безопасности, опознавания летательных аппаратов, авиационных станций активных радиопомех, корабельных комплексов радиоэлектронного подавления. В России разработаны собственные микросхемы, применяемые в загранпаспортах, платежных, социальных и транспортных картах. Компании автопрома, включая иностранные сборочные предприятия, до половины электронных компонентов получают от российских поставщиков.

Значительные достижения получены в сфере авионики - бортового радиоэлектронного оборудования самолетов и вертолетов, обеспечивающего коммуникацию, навигацию и управление. Когда создавался самолет SSJ-100, российские производители не были готовы оснастить его отечественным бортовым электронным оборудованием, поэтому вся электроника на этом самолете - европейского и американского производства. Но когда начались работы по конструированию самолета МС-21, 80\% его бортового радиоэлектронного оборудования и $90 \%$ программного продукта планировалось получить на российских предприятиях $[5$. С. 12, 17].

Перспективы импортозамещения намечены в государственной программе «Развитие электронной и радиоэлектронной промышленности» [6], цель которой - обеспечить страну к 2025 г. собственными средствами радиоэлектроники на $40 \%$, в том числе оборонную отрасль - на 90-95\%.

Поскольку электроника определяет все важнейшие технические параметры готовой продукции, недопустимо принудительное замещение ее импорта, если продукция-заменитель неконкурентоспособна. С учетом этого первоначальный вариант программы потребовал доработки в направлении снижения заданий по импортозамещению. По последней версии программы [7. С. 17] доля импортного оборудования должна составить в 2020 г. в телекоммуникационном оборудовании - 88\% (в 2025 г. - 70\%); в вычислительной технике - 97,6\% (93,3\%); в электронном машиностроении - 89\% (72,4\%); в системах интеллектуального управления - 80,3\% (в 2025 г. - 76,5\%).

Одним из приоритетов госпрограммы является производство вычислительной техники, в том числе персональных компьютеров. 
Низкий валютный курс рубля способствует созданию и локализации в России зарубежных сборочных производств и совместных предприятий.

\section{ИКТ и компьютеры}

Согласно определению, принятому Росстатом, под информационными и коммуникационными понимаются технологии, использующие средства микроэлектроники для сбора, хранения, обработки, поиска, передачи и представления данных, текстов, образов и звука.

ИКТ - новая быстроразвивающаяся отрасль. Благодаря заимствованию в сочетании с собственными достижениями российские ИКТ за короткий промежуток времени вышли на европейский уровень. Без этого Россия не смогла бы вписаться в глобальную экономику.

Доля организаций, использующих Интернет и электронную почту, с 2005 по 2013 гг. выросла с 53-56\% до 87-88\% (рис. 1). Доля организаций, использующих персональные компьютеры (ПК), уже в начале этого периода превышала 90\%, а в последующем выросла до 94\%.

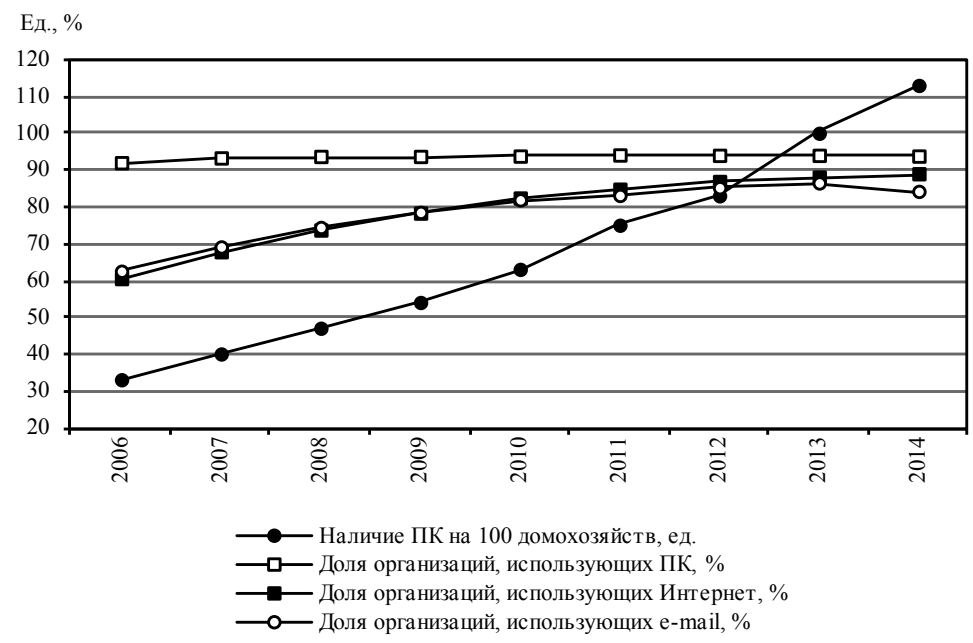

Рис. 1. Динамика использования ИКТ в России (ПК, Интернет, e-mail) в 2005-2013 гг. 
Наибольший рост наблюдался в использовании ПК населением. После 2005 г. их число на 100 домохозяйств выросло в четыре раза - с 26 до 100 компьютеров* (в Германии - 61 компьютер на 100 домохозяйств, в Японии - 116 ПК).

Российской экономике присуща высокая импортозависимость по вычислительной технике. Спрос на ПК удовлетворяется импортом на 95\% (из Китая - около 80\% импорта, США - 6\%, Германии $-2 \%)$.

Импортозамещение в сфере ПК идет по пути сборки в России компьютеров иностранных брендов. Попытка выпустить отечественную модель ПК, предпринятая в 1980-е гг., окончилась неудачей.

На рисунке 2 показан экспоненциальный рост сборочного производства ПК. Часть компьютеров российской сборки идет на экспорт. Российские ПК занимают до 75\% рынка Казахстана и Республики Беларусь. Основная часть компьютеров российской сборки поступает на внутренний рынок страны, вытесняя здесь импорт. Перспективы импортозамещения и развития экспорта вычислительной техники в обозримой перспективе будут зависеть в первую очередь от девальвации рубля и снижения доходов домашних хозяйств.

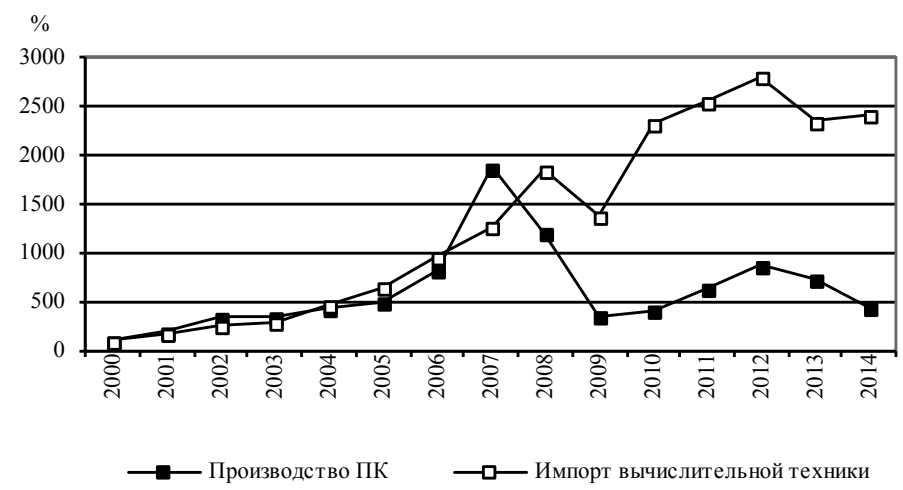

Рис. 2. Динамика производства ПК и импорта вычислительной техники в $2000-2013$ гг., \% (2000 г. = 100\%)

* Число компьютеров на 100 домохозяйств можно интерпретировать как процент обеспеченности населения ПК. 
Девальвация рубля повышает ценовую конкурентоспособность продукции, произведенной в России, как на внутреннем, так и на внешних рынках. Создаются благоприятные условия для роста российского сборочного производства компьютеров, уровня его локализации, экспорта продукции. Но падение мировых цен на нефть вызывает снижение курса национальной валюты не только в России, но и в других странах, торгующих нефтью. Доходы населения здесь также падают. Поэтому емкость рынков для российской продукции сокращается.

Снижение доходности в первую очередь подавляет спрос населения на более дорогую продукцию зарубежной сборки, тем самым способствуя ее импортозамещению более дешевой техникой отечественной сборки: в период сокращения доходов домашних хозяйств, вызванного кризисом 2008-2009 гг., импорт вычислительной техники снижался быстрее, чем собственное производство компьютеров (см. рис. 2). На графике видно, что в 2013 г. начался новый этап снижения импорта и производства вычислительной техники. В 2015 г. поставки ПК собственного и импортного производства сократились почти наполовину, в том числе портативных - на 50\%, настольных - на 36\%. В перспективе ожидается сокращение управленческих расходов, что вызовет падение спроса на ПК. Но если в целях безопасности предпочтение в госзакупках будет отдано вычислительной технике отечественного производства, то это ускорит импортозамещение.

Поскольку парк компьютеров приближается к точке насыщения, как в организациях, так и у населения, спрос будет определяться потребностью в замене техники, выбывающей вследствие быстрого обновления модельного ряда компьютеров.

В структуре спроса, производства и поставок компьютеров ожидается сохранение тенденции к росту мобильности, когда на потребительском рынке планшеты и ноутбуки вытесняют стационарные компьютеры. Намечается снижение импорта серверов, суперкомпьютеров, систем хранения данных.

\section{Программное обеспечение (софт)}

Программное обеспечение (ПО) занимает почти половину IT-бюджета компаний, несколько уступая затратам на «железо». Здесь преобладает импорт. По данным Минкомсвязи [8. С. 1,3; 9], импортозависимость России по софту составляет (\%): 
- в клиентских и мобильных операционных системах - 95;

- в сервисных операционных системах - 75;

- в системах управления базами данных - 86;

- в средствах управления облачной инфраструктурой и виртуализацией - 93;

- пользовательского офисного ПО - 97;

- в антивирусном ПО - 60;

- в интернет-сервисах, применяемых в корпоративной среде, -50 .

Импортозамещение ПО призвано обеспечить услуги связи и обработки информаџии. В связи с курсом на информационную безопасность ставится вопрос о переходе госзакупок импортного ПО на отечественные его разработки. Возможен даже запрет на приобретение импортного ПО.

Иностранные компании заинтересованы в сохранении российского рынка ПО. Так, один из крупнейших поставщиков ПО, немецкая компания SAP, для того чтобы в будущем участвовать в госзакупках на равных условиях с российскими компаниями, готова образовать с ними совместное предприятие. Девальвация рубля способствует реализации этих намерений.

На внутреннем рынке российские разработчики ПО устойчиво занимают те ниши, где зарубежным невыгодно подстраиваться под нашу специфику. Например, это бухгалтерский учет, отличный от мирового; системы распознавания и анализа текстов, в основе которых лежат семантические особенности русского языка; программы для оперативного управленческого учета, управления персоналом, начисления зарплаты. Скажем, программа $1 \mathrm{C}$ контролирует около одной трети российского рынка программ этого типа и обслуживает $80 \%$ автоматизированных рабочих мест.

По оценкам экспертов, сильной стороной российских ITкомпаний является создание базовых разработок и проектирование сложных процессов и систем. Российские компании предлагают на мировом рынке конкурентоспособное антивирусное программное обеспечение, управление хранением данных, оптическое распознавание символов и компьютерное зрение, обеспечение для процессинга банковских карт. Преимущества российского IT-рынка - невысокая стоимость рабочей силы по сравнению с США и странами Западной Европы, а также 
регулярный прирост числа потенциальных разработчиков: технические университеты ежегодно выпускают более 60 тыс. ІТ-специалистов [10. С. 20].

Под влиянием общего экономического спада рынок ITтехнологий в России начал сокращаться уже в 2013 г., причем впервые не только в валютном, но и в рублевом выражении. Эта тенденция сохранилась в 2014 г. Главная причина - падение спроса и продаж «железа» - персональных компьютеров, ноутбуков, серверов, сетевого оборудования. Между тем на оборудование в России приходится более половины выручки отрасли. На российский кризис здесь наложилась перестройка мирового спроса: он переключается на обработку больших объемов данных, интегрированные их хранилища, платформы из более дешевых серверов, способные обрабатывать гигантские массивы данных.

Импортозамещение выступает важной антикризисной мерой для IT-компаний. Но не ключевой. Главная антикризисная мера - развитие глобального экспорта программного обеспечения. О возможностях этого пути свидетельствует тот факт, что уже в 2013 г. экспорт программного продукта, разработанного в России, превысил 5 млрд долл.

Для успешной деятельности, в том числе и в кризис, российская IT-компания должна ориентироваться на глобальный рынок (отечественный занимает не более $1,5 \%$ от мирового). Для того чтобы финансировать крупные разработки, компаниям нужен выход на мировой рынок софта, чтобы сохранить бизнес даже в условиях стагнации российского рынка, компенсировать его падение за счет работы на иностранных площадках.

Дальнейшее развитие экспорта российского программного продукта покажем на примере трех IT-компаний.

Группа компаний «АйТи» [11. С. 20]

Первый крупный международный технологический проект этой компании стартовал в 1994 г., когда вместе с американской PTI была разработана платежная технология для смарт-карт. На ее основе был выполнен ряд проектов для России и стран СНГ. Затем была образована компания, ориентированная на заказную разработку программного обеспечения для зарубежного рынка. Одним из проектов стала разработка мобильного рабочего места, позволяющего использовать планшеты и смартфоны для корпоративных задач. 
Компания работала на рынках США, Великобритании, Германии. Был разработан софт для американской корпорации General Electric. Спустя несколько лет была получена оценка конкурентоспособности этой разработки: по сравнению с индийской она обошлась дороже, но качество было выше.

Компания Luxoft [12. С. 20]

С момента основания (2009 г.) компания ориентирована на рынки США и Западной Европы. Россия и другие страны Восточной Европы выступали как поставщики квалифицированного инженерного труда. Центры разработки - в Москве, в Украине, Румынии, Польше, Болгарии, Мексике. Среди клиентов - Deutsche Bank и UBS. Компания обеспечивает надежность разработок. В 2013 г. качество работы компании подтверждено проведением IPO на Нью-Йоркской бирже.

«ЭР-Телеком» [13. С. 10]

Один из крупнейших операторов платного ТВ (14\% российского рынка) и широкополосного доступа в Интернет (13\% рынка). «ЭР-Телеком Холдинг» намерен расти в ближайшие пять лет на 15-18\% в год. Ведется подготовка к выходу на IPO.

\section{Телефонная аппаратура}

По уровню телефонизации до недавнего времени наша страна катастрофически отставала не только от развитых, но и от большинства развивающихся стран. В расчете на 100 чел. населения в 1970 г. приходилось пять телефонных аппаратов, в 1980 г. $-9,7$ и в 1990 г. - 15,8. При численности семьи в 2,5 человека один телефон приходился соответственно на 10; 4 и 2,5 семьи. При этом уровень телефонизации сельского населения был в три раза ниже городского. Неоднократно принимаемые решения обеспечить телефоном каждую семью не выполнялись.

Выход из бедственного положения стране обеспечили сотовая связь и импорт телефонных аппаратов. В середине 1990-х годов дорогая мобильная связь была доступна лишь корпорациям. К началу XXI в. мобильные телефоны подешевели в 40 раз и стали широко доступны населению. Сотовые операторы, как российские, так и зарубежные, используя российскую спутниковую связь и отечественный сервис, смогли полностью телефонизировать страну. За 2000-2013 гг. импорт телефонных аппаратов вырос в 19 раз и составил в 2000 г. - 0,4 млрд долл., 
в 2005 г. - 1,2, 2008 г. - 8,0 и 2013 г. - 77 млрд долл. Свыше 60\% импорта пришлось на аппараты сотовой связи.

Китай поставляет в Россию более $40 \%$ импортных телефонных аппаратов, Вьетнам - около 10\%, остальное мы получаем из десятка других развивающихся стран с низкой стоимостью рабочей силы.

На рисунке 3 приведен график роста обеспеченности населения телефонными аппаратами. Сотовая связь росла существенно быстрее телефонной сети общего пользования. Если в 2000 г. обеспеченность населения сотовой связью была на порядок меньше, чем сети общего пользования, то в 2013 г. она уже существенно ее обгоняла: в расчете на 100 жителей приходилось 29 телефонных аппаратов сети общего пользования и 193 телефона сотовой связи, в расчете на семью - 5-6 телефонных аппаратов.

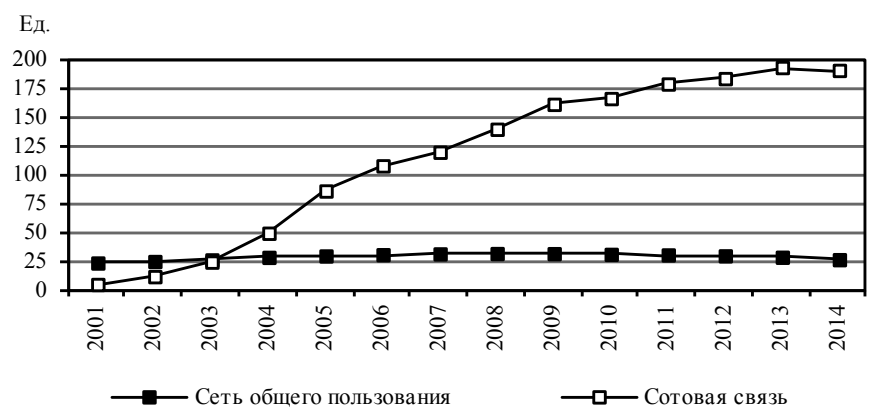

Рис. 3. Обеспеченность телефонными аппаратами населения в 2000-2013 гг., ед. на 100 чел.

Собственного производства телефонных аппаратов сотовой связи в промышленных масштабах в России нет. Перспективы импортозамещения будут определяться зависимостью не столько от отечественных разработок, сколько от стоимости собственной рабочей силы и условий для развития в стране иностранного сборочного производства.

С 2005 г. замещение происходит по линии сокращения числа квартирных телефонных аппаратов: в городе - с 270 до 238 ед. на 1000 жителей, на селе - со 113 до 108. Сотовая связь замещает стационарную телефонную. 


\section{Приемники телевизионные}

Объем производства телевизоров в стране к началу 1990-х годов составлял около 5 млн ед. В период кризиса 1990-х годов производство приемной телевизионной аппаратуры практически прекратилось. Крах производства был вызван полной неконкурентоспособностью отечественных телевизионных приемников в сравнении с японскими, южнокорейскими и т. д., снижением спроса населения из-за падения доходов в период кризиса, а также свертыванием финансирования оборонных предприятий, производивших телевизоры.

Новая эра обеспечения населения телевизионными приемниками началась на рубеже XXI в. (табл. 1). В благополучные 2000-е гг. поставки телевизоров в соответствии с возросшим спросом увеличились с 1,7 до 27,5 млн ед. - в 16 раз. Поставки росли как за счет импорта, так и собственного сборочного производства. Выпуск телевизоров отечественных марок в промышленных масштабах в России отсутствовал.

\section{Таблица 1. Телевизоры: производство, импорт, поставки} в 2000-2013 гг., млн ед.

\begin{tabular}{|l|c|c|c|c|c|}
\hline \multicolumn{1}{|c|}{ Показатель } & $\mathbf{2 0 0 0}$ & $\mathbf{2 0 1 0}$ & $\mathbf{2 0 1 1}$ & $\mathbf{2 0 1 2}$ & $\mathbf{2 0 1 3}$ \\
\hline Производство (ПР) & 1,1 & 12,0 & 14,7 & 16,2 & 14,7 \\
\hline Импорт (И) & 0,6 & 7,3 & 9,5 & 13,8 & 14,5 \\
\hline Поставки (ПР + И - Э) & 1,7 & 18,7 & 23,2 & 28,7 & 27,5 \\
\hline Доля импорта в поставках, \% & 35 & 39 & 41 & 48 & 53 \\
\hline
\end{tabular}

Данные таблицы свидетельствуют о том, что главная роль в поставках телевизионной техники принадлежала импорту. За 2000-2013 гг. импорт телевизоров увеличился с 0,6 до 14,5 млн ед. - в 24 раза. Доля импорта выросла с 35\% в 2000 г. до $69 \%$ в 2008 г. и $53 \%$ - в 2013 г. Основным поставщиком телевизионной аппаратуры в Россию является Китай (почти 50\% импорта). На Украину и Чехию приходится около $10 \%$ импорта, собранного в этих странах, остальное поставляют Словакия, Польша, Тайвань, Турция и другие страны с относительно дешевой рабочей силой.

Российское сборочное производство увеличилось за 20002013 гг. с 1,1 до 14,7 млн ед. - в 13 раз. Между сборочным производством и импортом развернулась конкурентная борьба. В 2006-2008 гг. импорт побеждает, обгоняя рост собственного 
сборочного производства. В ходе кризиса 2009 г. под влиянием падения доходов домашних хозяйств собственное сборочное производство начинает отыгрывать рынок у импорта. Продолжение этой тенденции ожидается в будущем под влиянием низкого валютного курса рубля, который способствует импортозамещению.

Более того, низкий валютный курс рубля может способствовать росту экспорта (Э) телевизоров отечественной сборки. Российский экспорт телевизоров не играл заметной роли вплоть до 2011 г. После этого он начал расти и к 2013 г. превысил 600 тыс. ед. (4\% от производства). Эта тенденция может сохраниться, но росту экспорта телевизоров отечественной сборки может препятствовать девальвация национальной валюты в странах ближнего зарубежья, которые, являясь главными покупателями техники российской сборки, сами зависят от мировых цен на нефть.

\section{Лекарства и медтехника}

Как лекарства, так и медтехника - это преимущественно высокотехнологичная продукция, применяемая в медицине для восстановления и поддержания здоровья населения. На приобретение лекарственных средств, приборов и устройств, используемых в медицине, хирургии, стоматологии и ветеринарии, рентгеновской аппаратуры альфа-, бета- и гамма-излучения Россия ежегодно тратит 15 млрд долл. После легковых автомобилей это - вторая по размерам статья расходов на импорт.

Бурный рост импорта лекарственных средств в Россию начался на рубеже 2000-х годов, когда после подорожания нефти в стране появились средства для его оплаты. В страну устремились алчные фармацевтические компании. Цены на лекарства росли, хотя, по визуальным наблюдениям, в Европе они не менялись.

За 2000-2013 гг. импорт лекарственных средств вырос с 1 млрд долл. до 12 млрд долл. (рис. 4). Этот процесс ускорялся по мере того, как дорожала нефть.

Основными поставщиками лекарственных средств в Россию являются Германия (20\%), Франция (11\%), Швейцария, Италия, Индия (каждая из стран - около 6-7\%). США поставляют в Россию около 3\% импортных лекарств. 
Млрд долл.

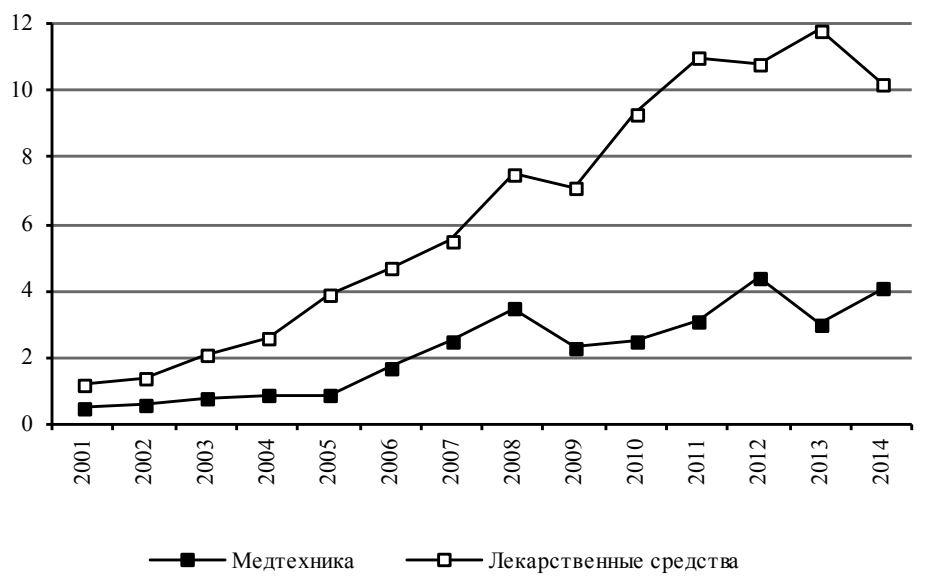

Рис. 4. Импорт медтехники и лекарственных средств в 2000-2013 гг., млрд долл.

Импортозамещение в области обеспечения страны лекарственными средствами происходило по двум направлениям: за счет роста их отечественного производства и перевода в Россию производств зарубежными компаниями. По сравнению с импортом производство отечественных лекарственных средств росло более скромными темпами. Так, с 2000 г. по 2013 г. отечественное производство лекарств в натуральном измерении (млн ампул, доз, упаковок) выросло по инсулину и другим средствам лечения сахарного диабета в пять раз. В 2-3 раза увеличилось российское производство лекарственных средств для лечения онкологических и психоневрологических заболеваний, дисбактериоза, болезней эндокринной системы, органов пищеварения. Российское производство противовоспалительных, жаропонижающих и болеутоляющих средств, широко востребованных населением, выросло за этот период всего в 1,2 раза. По нашим расчетам, в 2014 г. доля лекарств российского производства на внутреннем рынке составляла всего около $20 \%$, а по списку жизненно необходимых и важных лекарственных препаратов (ЖНВЛП) - 67\%. К 2018 г. намечено увеличить эту долю до 90\%. 
Согласно государственной программе развития фармацевтической и медицинской промышленности, к 2020 г. в этих отраслях намечается в семь раз повысить долю высокотехнологичной и наукоемкой продукции и до $50 \%$ довести долю лекарственных средств отечественного производства.

Российское производство лекарственных средств получает от государства различные преференции. Например, около одной трети российского рынка лекарственных средств реализуется через госзакупки, где действует правило «третий лишний»: при наличии двух отечественных поставщиков зарубежный производитель претендовать на госзакупки не может.

Российская фармацевтическая промышленность располагает предпосылками для замещения импорта как продукцией отечественного изготовления, так и зарубежными лекарственными средствами, производимыми на совместных предприятиях или зарубежными компаниями в пределах российской территории. К числу факторов, благоприятствующих импортозамещению, относятся большие масштабы российского рынка лекарственных средств, по объемам которого Россия занимает седьмое место в мире [14. С. 15]. В связи со старением населения российский рынок лекарств продолжает расти.

В стране реализуется 330 проектов разработки новых лекарств. Например, создан первый российский аналог противоопухолевого препарата. Начинается выпуск первого отечественного аналога инсулина. Национальная иммунобиологическая компания намечает полностью обеспечить внутренний рынок вакцинами и плазменными препаратами крови, занять 20\% рынка антивирусных препаратов, лекарств против ВИЧ и гепатитов.

По сравнению с импортом объем экспорта лекарственных средств ничтожно мал. Хотя за 2000-2013 гг. он и вырос вчетверо, но составил всего около 400 млн долл. - 3\% от объема импорта. Отечественная фармацевтическая промышленность неконкурентоспособна на мировом рынке. Однако выход на мировой рынок - важная предпосылка успешного импортозамешения на внутреннем рынке. Поэтому госпрограмма развития фармацевтической и медицинской промышленности предполагает увеличение экспорта продукции этих отраслей. 
Импорт медицинской техники (см. рис. 4) за 2000-2013 гг. вырос в 7,5 раза. Основными поставщиками в Россию импортных приборов и устройств, применяемых в медицине, хирургии, стоматологии, ветеринарии, рентгеновской аппаратуры, являются Германия (24\%), США (21\%), Япония (12\%), Китай (10\%).

Неконкурентоспособность российской медтехники по отношению к импорту в сочетании с кризисом 1990-х годов практически подавили ее отечественное производство (табл. 2).

Таблица 2. Российское производство

некоторых видов медтехники в 1990-2009 гг., тыс. ед.

\begin{tabular}{|l|c|c|c|c|c|}
\hline \multicolumn{1}{|c|}{ Медтехника } & $\mathbf{1 9 9 0}$ & $\mathbf{2 0 0 0}$ & $\mathbf{2 0 0 2}$ & $\mathbf{2 0 0 5}$ & $\mathbf{2 0 0 9}$ \\
\hline Наркозно-дыхательные аппараты & 37,1 & 4,9 & 1,9 & 2,7 & 1,0 \\
\hline Электрокардиографы & 23,0 & 9,8 & 6,5 & 2,6 & 1,6 \\
\hline Электрокардиостимуляторы имплантируемые & 19,6 & 6,0 & 7,8 & 7,9 & 9,5 \\
\hline
\end{tabular}

В 1990 г. в стране выпускалось 23 тыс. электрокардиографов, а в 2000 г. - вдвое меньше. К 2009 г. их производство сократилось в 14 раз - до 1,6 тыс. ед. Отечественное производство имплантируемых электрокардиостимуляторов упало к 2009 г. по сравнению с 1990 г. в два раза, при большом спросе на них.

После 2009 г. Росстат вообще прекратил публикацию данных об отечественном производстве медицинской техники, повидимому, из-за незначительности его объемов. В целом доля российских производителей медтехники на внутреннем рынке составляет 15-20\% [4]. По рентгеновской технике, флюорографии, маммографии она доходит до $60 \%$. На российском рынке хирургических инструментов она составляет примерно $30 \%$.

На мировом рынке российская медицинская промышленность, бесспорно, неконкурентоспособна: объем экспорта отечественной медтехники не превышает $2 \%$ от ее импортных закупок.

Ориентиры импортозамещения в области медтехники намечены в госпрограмме развития фармацевтической и медицинской промышленности. Ее выполнению может содействовать наличие собственного производства металлов и других материалов с особыми свойствами. 


\section{Экспортозамещение}

Понятие «экспортозамещение» можно определить как процесс компенсации снижения валютных поступлений от сырьевого экспорта за счет увеличения несырьевого: последний призван хотя бы частично восполнить убывание сырьевого.

Роль экспорта нефти, да и другого сырья в российской экономике настолько значительна, что компенсировать снижение доходов от ее экспорта только импортозамещением, возможно, не удастся. В.А. Мау вводит понятие «экспортоориентированное импортозамещение» [15. С. 448].

Экспортозамещение - это продолжение конкурентоспособного импортозамещения на внешнем рынке. Например, освоение российской металлургией производства газовых труб большого диаметра позволило не только отказаться от их импорта, но и поставлять трубы на экспорт. Другой пример. Замещение российской продукцией «ножек Буша» продолжилось поставками отечественного мяса птицы на экспорт.

Возможности импортозамещения, при прочих равных условиях, тем ограниченней, чем выше наукоемкость возмещаемого импорта. Состояние российской науки таково, что она располагает весьма ограниченными возможностями для создания собственных равноценных аналогов замещаемому импорту. При этом вклад нефти и другого сырья в российскую экономику неизбежно будет сокращаться из-за оскудения природных запасов, возможного снижения мировых цен, вызванного, например, «зеленой революцией», затуханием темпов роста мировой экономики, выводом на рынок новых технологий, появлением новых сырьевых стран и т. д.

Как уже было отмечено, у России нет шансов полностью отказаться от импорта многих видов высокотехнологичной продукции. Но для оплаты подорожавшего импорта доходов от продажи углеводородов при определенных условиях может не хватить, нагрузка на нефть может оказаться непосильной. Выход из этой ситуации способно обеспечить экспортозамещение: внешнеторговую нагрузку примет на себя одна из отраслей, имеющая достаточный потенциал для увеличения несырьевого экспорта. Например, развитие экспорта ПО может компенсировать импорт компьютеров, телефонных аппаратов, 
медицинской техники, другого «железа». В условиях низкого курса национальной валюты перспективы для экспортозамещения получают автопром, авиапром, многие другие сферы экономической деятельности, особенно если они обеспечивают конкурентность своей продукции, используя опыт передовых зарубежных компаний.

\section{$\star \star \star$}

Имортозамещение в сфере наукоемкой высокотехнологичной продукции при благоприятных внешних условиях может протекать в России за счет развития не только отечественных, но и западных и/ или совместных производств. Особенно эффективно импортозамещение в партнерстве с передовыми зарубежными компаниями. Выход на уровень конкурентоспособности собственных разработок достижим лишь по ограниченному числу высокотехнологичных продуктов. В ближайшее десятилетие Россия обречена на высокую импортозависимость по большинству видов наукоемкой высокотехнологичной продукции.

Но импортозамещение, основанное на заимствованиях и партнерстве с зарубежными производителями, предполагает устойчивость и стабильность мирохозяйственных связей, что в современной геополитической обстановке накладывает ограничения на его осуществление. Для того чтобы импортозамещение было эффективным, целесообразно выбрать ограниченный круг приоритетных проектов и предприятий, обеспечить их инвестиционную привлекательность, сконцентрировать ресурсы на их реализации.

Вынужденное (принудительное) импортозамещение без учета конкурентоспособности продукции-заменителя способно на десятилетия отбросить страну назад. Например, первоначальная программа импортозамещения более 500 продуктов электроники и IT-технологий оказалась избыточной и потребовала серьезного сокращения для поддержания высокого качества связи [7].

Устойчивая сбалансированность внутрироссийского спроса на высокотехнологичную продукцию может быть достигнута за счет сочетания импортозамещения с экспортозамещением. 


\section{Литература}

1. Фальцман В. К. Импортозамешение в ТЭК и ОПК // Вопросы экономики. - 2015. - № 1. - С. 116-124.

2. Фальцман В.К. Диверсификация российской экономики // Вопросы экономики. - 2015. - № 5. - С. 48-62.

3. Фальцман В.К. Импортозамещение в отраслях экономики России // Проблемы пргнозирования. - 2015. - № 5 (152). - С. 52-62. 4. Фальцман В.К. Продовольственная импортонезависимость России // ЭКО. - 2015. - № 5. - С.127-140.

5. Bussiness Guide. Радиоэлектронные технологии // Приложение к газете Коммерсантъ. - 2014. - № 75.

6. URL: www. Russianelektroniks. Ru (дата обращения: 25.11.2015).

7. Кантышев П. Импорт быстро не замещается// Ведомости. 2015. - 2 нояб.

8. Коммерсантъ. - 2015. - № 61.

9. Коммерсантъ. - 2015. - № 59/П.

10. Review Технологии на экспорт // Тематическое приложение к газете Коммерсантъ. - 2014. - № 220.

11. Япаров T. Интервью председателя совета директоров группы компаний «Ай Ти» // Коммерсантъ. - 2014. - № 220.

12. Лощинин Д. Интервью генерального директора Luxoft // Коммерсантъ. - 2014. - № 220.

13. Кузяев А. Интервью президента копании «ЭР-Телеком»// Коммерсантъ. - 2015. - № 40 / В.

14. Цыб С. Интервью зам. главы Минпромторга. Расширяя номенклатуру постановлений // Ведомости. - 2015. - № 101.

15. Мау В. Кризисы и уроки. Экономика России в эпоху турбулентности// М.: Изд-во Института Гайдара, 2016. 


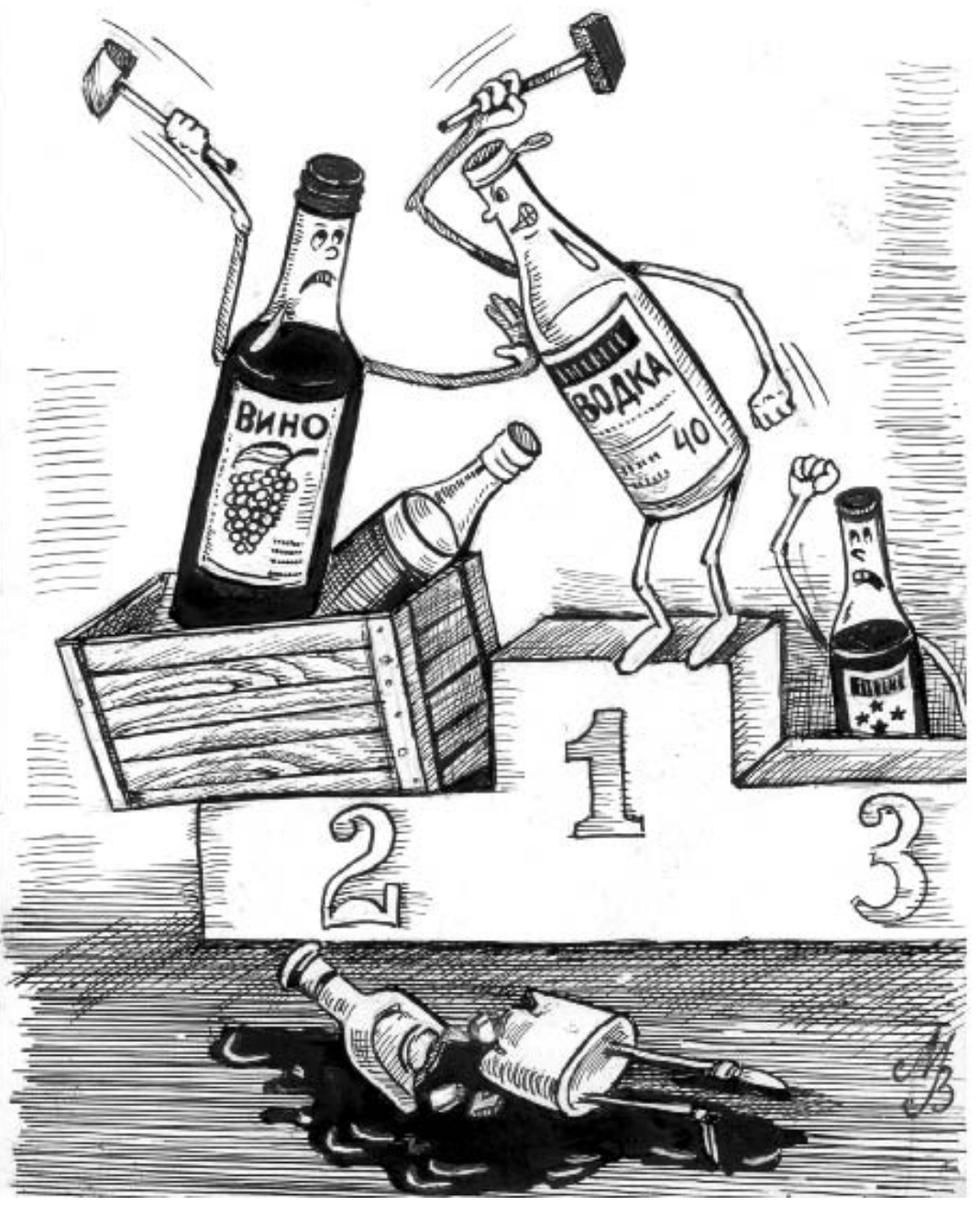




\section{«Не с того конца взялись»: перспективы развития рынка вина в России}

E.C. КАРПУШИН, кандидат экономических наук. E-mail: mfisk@yandex.ru А.С. СоловьЁвА, Балтийский гуманитарный институт, Санкт-Петербург. E-mail: alinas25@mail.ru

В статье анализируются перспективы развития российского рынка вина, основные тенденции в данном направлении и прогнозы изменения ситуации на нем с учетом сложившейся негативной ситуации в экономике России. Указываются главные недостатки и проблемы развития российского виноделия. Формируются рекомендации производителям вина по усилению и созданию отечественных брендов, активизации маркетинговой активности.

Ключевые слова: вино, рынок, импортозамещение, потребление, контрафакт

В настоящее время мировая винодельческая отрасль переживает не лучшие времена, что связано с обострением конкуренции, однако виноделие по-прежнему занимает особое место в экономике стран, являющихся экспортерами и импортерами этого продукта, поскольку обеспечивает значительные поступления в бюджеты. Винопроизводство в России, несмотря на все трудности, с которыми ему пришлось столкнуться (мировой кризис, программы по борьбе с алкоголизмом, нехватка достаточного количества собственного виноградного сырья), характеризовалось в начале XXI века значительным ростом вследствие успешной реализации программ по обновлению промышленных мощностей.

Для России повышение интереса к данной отрасли было вызвано присоединением Крыма, обладающего обширными производственными возможностями. Значение виноделия подкрепляется стремлением Минздрава РФ решить важную социально-экономическую задачу по снижению алкоголизации населения за счет повышения потребления вина среди населения при параллельном сокращении доли крепкого алкоголя (повышение культуры потребления алкоголя). На это, в частности, указывает директор Федерального медицинского исследовательского центра психиатрии и наркологии Минздрава Т. Клименко [1]. 